\title{
KEABSAHAN UJIAN PENGANGKATAN NOTARIS SEBAGAI SYARAT PENGANGKATAN NOTARIS
}

\author{
Febriyan Adis Firmansyah \\ Magister Kenotariatan Universitas Narotama Surabaya \\ Email : febriyan.adis2018@gmail.com \\ Habib Adjie \\ Magister Kenotariatan Universitas Narotama Surabaya \\ Email : adjieku61@gmail.com
}

\begin{abstract}
ABSTRAK
Diundangkannya Peraturan Menteri Hukum Dam Hak Asasi Manusia Nomor 25 Tahun 2017 Ujian Pengangkatan Notaris menjadi permasalahan karena Undang-Undang Jabatan Notaris sebagai peraturan yang lebih tinggi kedudukannya tidak mensyaratkan adanya Ujian Pengangkatan sebagai syarat pengangkatan Notaris.

Penulis dalam penelitian ini ingin menelaah dan menganalisa lebih lanjut tentang ratio legis adanya persyaratan Ujian Pengangkatan Notaris dan daya laku Peraturan Menteri Hukum Dam Hak Asasi Manusia Nomor 25 Tahun 2017 Ujian Pengangkatan Notaris.

Metode penelitian yang digunakan adalah penelitian hukum normatif, yaitu penelitian hukum yang dilakukan dengan cara meneliti bahan pustaka atau bahan hukum sekunder sedangkan pendekatan masalah dilakukan dengan menggunakan pendekatan undang-undang dan pendekatan konseptual.

Hasil penelitian menunjukkan bahwa yang menjadi ratio legis adanya persyaratan Ujian Pengangkatan Notaris adalah untuk mendapatkan standarisasi dan kualitas tinggi dari tiap Notaris yang akan diangkat sehingga didapatkan Notaris yang benar-benar memiliki pengetahuan yang mumpuni. Peraturan Menteri Hukum Dam Hak Asasi Manusia Nomor 25 Tahun 2017 Ujian Pengangkatan Notaris tidak memiliki daya laku karena meskipun dibentuk berdasarkan kewenangan Menteri tetapi bertentangan dengan peraturan yang kedudukannya lebih tinggi.
\end{abstract}

Kata kunci : Notaris, Peraturan Menteri, Ujian Pengangkatan

\section{ABSTRACT}

Stipulation of Ministry of Law and Human Rights Decree No 25, 2017 concerning exam for candidate of notary public becomes public debate since Law of Notary Public (UUJN) as the highest regulation did not require national exam for the candidate of notary public as the requirement to become notary public.

The present study tries to elaborate and examine further about ratio legisof exam for notary public candidate as the requirement to become notary public that is stipulated by the Ministry of Law and Human Rights No 25, 2017.

The method used in the present study is a normative legal research, namely legal research which is conducted by examining the library materials or secondary law while in finding and collecting the data is done by two approaches, namely the law and conceptual approaches. 
The present study concludes that ratio legisof exam for notary public candidate as the requirement to become notary public is to achieve high standard coupled with quality of notary public that will be inaugurated. The Ministry of Law and Human Rights decree No 25, 2017 concerning examination for notary public candidate does not hold legal power since it is contradiction with the highest regulation about notary public or Law of Notary Public (UUJN).

Keywords: Notary Public, Decree of Minister, Inauguration Exam

\section{Pendahuluan}

Kedudukan notaris sebagai seorang pejabat umum merupakan suatu jabatan terhormat yang diberikan oleh Negara secara atributif melalui Undang-Undang kepada seseorang yang dipercayainya dan yang mengangkatnya adalah Menteri demikian berdasarkan ketentuan dalam Pasal 2 Undangundang Nomor 30 Tahun 2004 tentang Jabatan Notaris sebagaimana telah diubah dengan Undang-undang Nomor 02 Tahun 2014 tentang Perubahan Atas Undang-Undang Nomor 30 Tahun 2004 tentang Jabatan Notaris (UUJN) yang menyatakan "Notaris diangkat dan diberhentikan oleh Menteri" (Habib Adjie;2008;23). Menteri yang dimaksud dalam Pasal 2 UUJN tersebut adalah Menteri Hukum Dan Hak Asasi Manusia sebagaimana ditegaskan dalam Pasal 1 angka 14 Peraturan Menteri Hukum Dan Hak Asasi Manusia Republik Indonesia Nomor 25 Tahun 2014 Tentang Syarat Dan Tata Cara Pengangkatan, Perpindahan, Pemberhentian, Dan Perpanjangan Masa Jabatan Notaris, yang menyatakan : "Menteri adalah Menteri Hukum dan Hak Asasi Manusia".

Menurut Habib Adjie, dengan diangkatnya seorang Notaris oleh Menteri, maka seorang Notaris dapat menjalankan tugasnya dengan bebas, tanpa dipengaruhi badan eksekutif dan badan lainnya. Maksud kebebasan disini adalah supaya profesi Notaris nantinya tidak akan takut untuk menjalankan jabatannya, sehingga dapat bertindak netral dan independen (Habib Adjie dalam Rusdianto Sesung;2017;57).

Dalam istilah sehari-hari istilah Independen ini sering disama-artikan dengan Mandiri. Dalam konsep Manajemen bahwa penerapan istilah Mandiri berarti institusi yang bersangkutan secara manajerial dapat berdiri sendiri tanpa bergantung kepada (depend on) atasannya. Sedangkan Independen baik secara manajerial maupun institusional tidak tergantung kepada atasannya ataupun kepada pihak lainnya. Independen ini mempersoalkan kemerdekaan Pejabat Umum dari intervensi atau pengaruh pihak lain ataupun diberi tugas oleh instansi lain (Habib Adjie dalam Rusdianto Sesung;2017;31-32).

Notaris oleh undang-undang diberi wewenang untuk menuangkan semua perbuatan, perjanjian dan penetapan yang dikehendaki oleh pihak atau pihakpihak yang sengaja datang kehadapan Notaris untuk mengkonstatir keterangan itu dalam suatu akta otentik, dan agar akta yang dibuatnya itu memiliki kekuatan bukti yang lengkap dan memiliki keabsahannya (Suhardjono;1995;133-135).

Kedudukan Notaris sebagai suatu jabatan yang terhormat dan memiliki peran sangat penting dalam masyarakat tentunya mengharuskan siapa yang memangku jabatan tersebut memiliki kualitas yang mumpuni baik secara keilmuan maupun kepemimpinan. Ilmu pengetahuan khususnya di bidang 
hukum harus benar-benar dipahami oleh Notaris secara mendalam.

Kebutuhan akan Notaris yang memiliki kemampuan dan kualitas yang mumpuni tersebut direspon pemerintah dengan diundangkannya Peraturan Menteri Hukum Dan Hak Asasi Manusia Nomor 25 Tahun 2017 Tentang Ujian Pengangkatan Notaris (Permenkumham 25/2017). Lahirnya peraturan tersebut menjadi awal adanya syarat Ujian Pengangkatan bagi calon Notaris yang hendak mengajukan permohonan pengangkatan.

Tujuan dari diadakannya Ujian Pengkatan bagi calon Notaris tersebut adalah untuk mengetahui bagaimana kompetensi dari calon Notaris. Hal ini disebutkan dalam Pasal 1 angka 1 Permenkumham 25/2017 : "Ujian Pengangkatan Notaris yang selanjutnya disebut Ujian adalah mekanisme untuk mengetahui kompetensi dan memperoleh tanda lulus ujian pengangkatan Notaris."

Permenkumham 25/2017 tersebut menjadi tindak lanjut dari diletakkannya syarat kelengkapan dokumen berupa tanda kelulusan ujian pengangkatan Notaris yang disebutkan dalam Pasal 2 ayat (2) huruf j Peraturan Menteri Hukum Dan Hak Asasi Manusia Nomor 62 Tahun 2016 Tentang Perubahan Atas Peraturan Menteri Hukum Dan Hak Asasi Manusia Nomor 25 Tahun 2014 Tentang Syarat Dan Tata Cara Pengangkatan, Perpindahan, Pemberhentian, Dan Perpanjangan Masa Jabatan Notaris (Permenkumham 62/2016) yang menyatakan : "Persyaratan sebagaimana dimaksud pada ayat (1), harus dibuktikan dengan kelengkapan dokumen pendukung yang meliputi : ... j. fotokopi tanda kelulusan ujian pengangkatan Notaris yang diselengarakan oleh Direktorat Jenderal
Administrasi Hukum Umum yang telah dilegalisasi;"

Ketentuan mengenai adanya syarat Ujian Pengangkatan bagi Calon Notaris tersebut di satu sisi memiliki dampak positif terlebih dengan semakin menjamurnya penyelenggara Program Studi Magister Kenotariatan di Indonesia maka memang sudah selayaknya ada suatu filter dalam pengangkatan Notaris. Di Sisi lain adanya ketentuan tersebut menimbulkan pro dan kontra karena UUJN tidak mensyaratkan adanya Ujian Pengangkatan sebagai syarat pengangkatan Notaris.

Pasal 3 UUJN sebagai dasar untuk pengangkatan Notaris tidak menyebutkan adanya Ujian Pengangkatan sebagai syarat untuk diangkat menjadi Notaris. Kondisi tersebut memunculkan pokok permasalahan yang akan dikaji dalam penelitian ini, yaitu mengenai kedudukan Ujian Pengangkatan dalam syarat pengangkatan Notaris, khususnya terkait konflik Norma yang terjadi akibat adanya pertentangan dalam Pasal 3 UUJN dengan ketentuan dalam Permenkumham 62/2016 jo. Permenkumham 25/2017.

\section{Rumusan Masalah}

1) Apa ratio legis adanya syarat Ujian Pengangkatan Notaris?

2) Apakah Menteri Hukum Dan Hak Asasi Manusia berwenang mengeluarkan peraturan tentang Ujian Pengankatan Notaris?

\section{Metode Penelitian}

Penelitian ini menggunakan metode penelitian hukum normatif yang dilakukan untuk mencari pemecahan masalah atas permasalahan hukum yang ada. Pendekatan penelitian yang digunakan adalah pendekatan undang- 
undang (statute approach) dan pendekatan konseptual (conceptual approach).

\section{Pembahasan \\ Ratio Legis Diberlakukannya Ujian Pengangkatan Notaris}

Lembaga Notaris mulai masuk di Indonesia pada awal abad ke-XVII seiring dengan keberadaan Vereenigde Oost Ind. Compaignie (VOC) di Indonesia (G.H.S. Lumban Tobing;1979). Pada awal abad XVII Pemerintah Kolonial Belanda meluaskan wilayah jajahannya ke Asia termasuk ke wilayah kepulauan Indonesia yang kemudian dikenal dengan sebutan kepulauan Hindia Belanda. Aktivitas perdagangan yang dilakukan $V O C$ pada masa itu membawa dampak dibutuhkannya tenaga profesional pembuatan surat libel, akta perjanjian, akta yang berkaitan dengan perdagangan dan akta-akta lain yang dapat dijadikan sebagai alat bukti tertulis (A.A. Andi Prajitno;2015).

Jan Pieterszoon Coen yang pada saat itu menjabat sebagai Gubernur Jendral di Jacatra (Jakarta sekarang) antara tahun 1671 sampai 1629 menganggap untuk keperluan para penduduk dan pedagang di Jakarta perlu mengangkat seorang notaris, yang disebut Notarium Publicum. Notaris pertama yang diangkat di Indonesia adalah Melchior Kerchem, sekretaris College van Schepenen pada tanggal 27 Agustus 1620. Melchior Kerchem kemudian dalam sejarah notaris dikenal sebagai notaris pertama di Indonesia. Dalam surat pengangkatannya sebagai Notaris pertama, tugas Melchior Kerchem melayani dan melakukan semua surat libel (smaadscrift), surat wasiat di bawah tangan (codicil), persiapan penerangan, akta perjanjian perdagangan, perjanjian kawin, surat wasiat (testament) dan akta-akta lainnya dan ketentuan-ketentuan yang perlu dari kotapraja (Komar;1981;37).

Pada tahun 1860 Pemerintah Hindia Belanda memandang perlu untuk membuat peraturan-peraturan yang baru mengenai Jabatan Notaris di Nederlands Indie untuk disesuaikan dengan peraturan-peraturan jabatan Notaris yang berlaku di Belanda Jabatan Notaris pada waktu itu tidak mempunyai sifat yang merdeka, berbeda halnya dengan sekarang ini, oleh karena para Notaris pada waktu itu tetap merupakan pegawai dari "Oost Indische Compaign" yang dibentuk untuk kepentingan negara atau pemerintah Belanda (Andi Prajitno, Op. Ci;13). Pengangkatan Notaris di Indonesia di wilayah Hindia Belanda pada waktu itu bertujuan untuk mengatur persaingan dagang yang berlatar belakang penjajahan. Hal ini dilakukan dengan menguasai bidang perdagangan secara monopoli dan sekaligus pengukuhan penguasaan wilayah jajahan pemerintah Belanda di bumi Nusantara (Andi Prajitno).

Istilah atau sebutan dari jabatan Notaris tersebut di Indonesia lebih dikenal dengan pejabat umum atau openbaar ambtenaar pada zaman pemerintahan penjajah Hindia Belanda. Pada masa ini Notaris diangkat oleh pemerintah Hindia Belanda dari kalangan orang-orang pemerintahan, umumnya orang Belanda atau orang barat yang diberi kesempatan mengikuti pendidikan khusus, diklat (pendidikan kilat) yang diselenggarakan oleh pemerintah Hindia Belanda. Keadaan seperti ini lambat laun berakhir sejak proklamasi kemerdekaan Negara Kesatuan Republik Indonesia tanggal 17 Agustus 1945. Indonesia merdeka maka banyak orang Belanda, karyawan sipil Belanda, termasuk Notaris Belanda yang 
pulang ke negaranya (Andi Prajitno, $O p$. Cit.).

Setelah Indonesia merdeka, 17 Agustus 1945, keberadaan Notaris di Indonesia tetap diakui berdasarkan ketentuan Aturan Peralihan UndangUndang Dasar 1945. Aturan tersebut membawa konsekuensi bahwa Reglement op Het Notaris Ambt in Nederlands Indie (Stbl. 1860:3) tetap diberlakukan (Habib Adjie, Op.Cit;5).

Pada tanggal 13 November 1954 Pemerintah Republik Indonesia mengeluarkan Undang-Undang Nomor 33 Tahun 1954 tentang Wakil Notaris dan Wakil Notaris Sementara Lembaran Negara Republik Indonesia Tahun 1954 Nomor 101, Tambahan Lembaran Negara Republik Indonesia Tahun 1954 Nomor 700. Berlakunya UU tersebut juga sekaligus menegaskan berlakunya Reglement op Het Notaris Ambt in Nederlands Indie sebagai Reglemen untuk notaris di Indonesia dan dikenal dengan nama Peraturan Jabatan Notaris (PJN).

$\begin{array}{ccr}\text { Setelah } & \text { Indonesia } & \text { merdeka, } \\ \text { pemerintah } & \text { tidak } & \text { segera }\end{array}$
mengembangkan konsep peraturan baru bagi Lembaga Notaris. PJN yang berlaku sejak 1860 terus dipakai sebagai satusatunya Undang-Undang yang mengatur Lembaga Notaris di Indonesia meskipun dilihat dari berbagai aspek PJN sudah tidak sesuai dengan perkembangan jaman. Undang-Undang yang menjadi awal lahirnya PJN yaitu Notariswet sendiri telah beberapa kali mengalami perubahan untuk menyesuaikan diri dengan perkembangan hukum dan bisnis di negara Belanda (Pengurus Pusat Ikatan Notaris Indonesia;2008).

Notaris dalam menjalankan jabatannya harus berlandaskan pada asas pemberian alasan. Dalam hal ini Notaris harus memiliki alasan serta fakta yang mendukung dalam akta yang dibuatnya, selain itu Notaris harus dapat memberikan pengertian hukum kepada para penghadap terhadap akta yang dibuatnya tersebut. Notaris merupakan pejabat umum yang diciptakan negara sebagai implementasi dari negara dalam memberikan pelayanan kepada rakyat yang merupakan jabatan yang istimewa, luhur, terhormat dan bermartabat karena secara khusus diatur dengan undang-undang tersendiri mengenai jabatan tersebut.

Menurut Tan Thong Kie, masyarakat membutuhkan seseorang (figuur) yang keterangan-keterangannya dapat diandalkan, dapat dipercayai, yang tanda tangannya serta segelnya (capnya) memberi bukti kuat, seorang ahli yang tidak memihak dan penasihat yang tidak ada cacatnya (onkreukbaar atau unimpeachable), yang tutup mulut, dan membuat suatu perjanjian yang dapat melindunginya di hari-hari yang akan datang. Kalau seorang advokat membela hak-hak seseorang ketika timbul suatu kesulitan, maka seorang notaris harus berusaha mencegah terjadinya kesulitan itu (Tan Thong Kie;2000).

Arti pentingnya keberadaan Notaris juga ditegaskan oleh Hatta Isnaini Wahyu Utomo, bahwa Notaris sebagai kepanjangan tangan dari pemerintah untuk melayani masyarakat yang membutuhkan alat bukti berupa akta otentik diharapkan mempunyai kualitas keilmuan yang mumpuni sehingga mampu memberikan rasa aman bagi masyarakat yang datang menghadap kepada Notaris serta mampu memberikan kepastian hukum dan perlindungan hukum. Untuk mencapai tujuan tersebut disyaratkan dalam Pasal 3 huruf e UUJN bahwa untuk dapat diangkat menjadi Notaris harus berijazah sarjana hukum dan lulusan jenjang strata dua kenotariatan. 
Adanya syarat tersebut diharapkan bahwa Notaris merupakan sosok yang menguasai hukum khususnya di bidang hukum privat sehingga dari akta yang dibuatnya mampu melindungi kepentingan masyarakat (Hatta Isnaini Wahyu Utomo;2018;14).

Untuk mendapatkan Notaris yang berkualitas pemerintah, dalam hal ini melalui Menteri Hukum dan Hak Asasi Manusia memberlakukan syarat ujian pengangkatan Notaris. Sebelum diberlakukannya UUJN telah disebutkan dengan adanya ujian sebagai salah satu syarat pengangkatan Notaris. Dalam PJN yang berlaku sejak 1860 hingga dikeluarkannya UUJN telah diatur bahwa untuk dapat menjadi Notaris harus melalui ujian. Ujian Notaris sebagaimana diatur dalam Peraturan Jabatan Notaris (PJN) adalah ujian negara, artinya ujian tersebut diselenggarakan oleh negara. Pelaksanaannya adalah tiap kali ada ujian maka dibentuk panitia ujian oleh Departemen Kehakiman sebagaimana maksud dalam Pasal 14 PJN. Dalam hubungannya dengan pendidikan dan pembinaan profesi Notaris, akhir-akhir ini terlihat dengan jelas bahwa perhatian pemerintah semakin besar. Hal ini dimaksudkan agar ada peningkatan mutu dan pendidikan Notaris, dan juga dalam pengabdiannya kepada masyarakat umum (Freddy Harris dan Leny Helena;2017).

Dalam kehidupan yang dinamis sekarang ini, Notaris juga harus mempunyai kemampuan untuk dapat mempunyai visi kedepan. Disamping itu seorang Notaris harus juga mempunyai ciri kualitas manusia yang senantiasa berakhlak sempurna dalam segala tingkah lakunya. Mampu menjaga hubungannya secara baik antara rekan seprofesi, masyarakat, organisasi dan pemerintahan yang menaunginya.
Kementerian Hukum dan Hak Asasi Manusia Republik Indonesia akan menyelenggarakan Ujian Pengangkatan Notaris.

Menurut Freddy Harris, Ujian pengangkatan ditujukan agar dapat adanya standarisasi dan kualitas tinggi dari tiap Notaris yang dapat diangkat ataupun menempati daerah tertentu. Karena Notaris tersebut harus menjawab tantangan Jabatan yang harus diembannya. Lulus Ujian Kompetensi Notaris adalah syarat yang harus dipenuhi bagi para Notaris yang ingin diangkat pertama kali. Ujian ini dilaksanakan secara berkala setahun sekali dengan sistem ujian tertulis berbentuk essay. Dengan jumlah pertanyaan yang secara terukur dapat menilai kemampuan calon Notaris, bahwa memang secara nyata mempunyai pengetahuan yang cukup, baik dan layak menjadi seorang Notaris. Ujian tertulis dimaksudkan untuk mengukur pengetahuan calon Notaris atau Notaris pindahan bersangkutan. Meliputi berbagai peraturan yang mengatur dalam akta-akta yang dibuat oleh Notaris, antara lain namun tidak terbatas pada hukum perikatan, hukum perorangan dan keluarga, perkumpulan dan badan hukum Selama ini selalu terjadi para Notaris sama sekali tidak berpengetahuan cukup untuk diangkat menjadi Notaris Sehingga ketika diangkat menjadi Notaris terjadi berbagai macam kesalahan, kekeliruan dan penyimpangan yang sangat merugikan masyarakat dan mencemarkan nama baik profesi Notaris (Freddy Harris dan Leny Helena;103). Melalui diundangkannya Permenkumham 25/2017 harus ditegaskan bahwa tidak ada kelalaian sedemikian kecilnya yang dapat diabaikan ataupun kesalahan yang sedemikian besarnya yang tidak bisa 
dihindarkan. Setiap pelanggaran tersebut sebaiknya sudah sejak awal dapat diantisipasi Notaris mempunyai pengetahuan dan juga kemampuan yang cukup dalam menjalankan profesinya dan hal tersebut diatur melalui diberlakukannya syarat Ujian Pengangkatan Notaris. Ujian Pengangkatan adalah salah satu cara mengukur bahwa Notaris yang bersangkutan benar-benar memiliki pengetahuan yang cukup selain persyaratan administratif lainnya, karena jangka waktu menjabat atau pun jumlah akta yang telah dibuat oleh Notaris tidak bisa menjamin bahwa Notaris tersebut siap dan kompeten.

\section{Kewenangan Menteri Hukum Dan Hak Asasi Manusia Dalam Mengeluarkan Peraturan Tentang Ujian Pengangkatan Notaris}

Presiden dalam menjalankan pemerintahannya dibantu oleh Menteri. Hal tersebut ditegaskan dalam Pasal 17 Undang-Undang Negara Republik Indonesia Tahun 1945. Setiap Menteri membidangi urusan tertentu dalam pemerintahan. Dalam menjalankan urusan tertentu dalam pemerintahan tersebut Menteri diberi kewenangan untuk mengeluarkan Peraturan Menteri. Dalam konteks eksistensi Peraturan Menteri di Indonesia, maka dengan berpijak pada tugas dan fungsi Menteri sesuai dengan 17 UUD NRI 1945, Maria Farida Indrati merumuskan fungsi Peraturan Menteri sebagai berikut ini : a) Menyelenggarakan pengaturan secara umum dalam rangka penyelenggaraan kekuasaan pemerintahan di bidangnya. b) Menyelenggarakan pengaturan lebih lanjut ketentuan dalam peraturan presiden. c) Menyelenggarakan pengaturan lebih lanjut ketentuan dalam Undang-undang yang tegas-tegas menyebutnya. d) Menyelenggarakan pengaturan lebih lanjut ketentuan dalam Peraturan Pemerintah yang tegas-tegas menyebutnya (Maria Farida Indrati;2014;57).

Kewenangan Menteri untuk mengeluarkan Peraturan Menteri semakin ditegaskan dengan diundangkannya Undang Undang Nomor 12 Tahun 2011 Tentang Pembentukan Peraturan Perundang-Undangan (UU 12/2011). Pada Pasal 8 ayat (1) UU 12/2011 disebutkan tentang Peraturan Menteri. Dalam Penjelasan Pasal 8 ayat (1) UU 12/2011 dijelaskan bahwa yang dimaksud dengan "Peraturan Menteri" adalah peraturan yang ditetapkan oleh menteri berdasarkan materi muatan dalam rangka penyelenggaraan urusan tertentu dalam pemerintahan. Oleh karena itu, Peraturan Menteri menjadi menjadi entitas sistem hukum bidang perundang-undangan dan merupakan bagian terpenting dalam mengatur tata laksana pemerintahan agar dapat terlaksana sesuai dengan fungsi kementerian itu sendiri

Selanjutnya disebutkan pada Pasal 8 ayat (2) UU 12/2011 bahwa Peraturan Perundang-undangan seperti Peraturan Menteri diakui keberadaannya dan mempunyai kekuatan hukum mengikat sepanjang diperintahkan oleh Peraturan Perundang-undangan yang lebih tinggi atau dibentuk berdasarkan kewenangan. Dari ketentuan di atas, terdapat dua syarat agar peraturan-peraturan sebagaimana dimaksud dalam Pasal 8 ayat (1) UU 12/ 2011 memiliki kekuatan mengikat sebagai peraturan perundangundangan, yaitu : 1) diperintahkan oleh peraturan perundang-undangan yang lebih tinggi; atau 2) dibentuk berdasarkan kewenangan.

Dalam doktrin, hanya dikenal dua macam peraturan perundang-undangan dilihat dasar kewenangan pembentukannya, yaitu peraturan 
perundang-undangan yang dibentuk atas dasar : 1) atribusi pembentukan peraturan perundang-undangan; dan 2) delegasi pembentukan peraturan perundang-undangan. Berkaitan dengan hal tersebut A. Hamid S. Attamimmi menegaskan Atribusi kewenangan perundang-undangan diartikan penciptaan wewenang (baru) oleh konstitusi/grondwet atau oleh pembentuk undang-undang (wetgever) yang diberikan kepada suatu organ negara, baik yang sudah ada maupun yang dibentuk baruuntuk itu. Sementara itu, delegasi dalam bidang perundangundangan ialah pemindahan/ penyerahankewenangan untuk membentuk peraturan dari pemegang kewenangan asal yang memberi delegasi (delegans) kepada yang menerima delegasi (delegataris) dengan tanggungjawab pelaksanaan kewenangan tersebut pada delegataris sendiri, sedangkan tanggungjawab delegans terbatas sekali (A. Hamid S. Attamimmi;1990;352).

Materi muatan peraturan delegasi hanya dapat mengatur hal yang didelegasikan dan tidak boleh bertentangan dengan peraturan perundang-undangan lain yang lebih tinggi tingkatannya. Sehingga UndangUndang atau Peraturan Pemerintah yang mendelegasikan harus diatur secara tegas bentuk dan ruang lingkup peraturan delegasi. Jika materi muatan peraturan delegasi melebihi muatan delegasi, maka batal demi hukum (van rechtswege nietig void) karena ditetapkan oleh pejabat yang tidak berwenang (Bagir Manan;1992).

Menurut HAS Natabaya, pada dasarnya menteri sebagai pejabat negara didirinya melekat tiga kewenangan untuk membuat keputusan, yaitu keputusan, yaitu keputusanyang bersifat penetapan (beschikking), misalnya menetapkan pengangkatan pejabat di lingkungan kerjanya. Menteri juga mempunyai kewenangan untuk membuat aturan kebijakan (beleidsregels) yang tidak didasarkan kepada suatu peraturan perundangundangan tetapi didasarkan kepada freis ermessen atau kewenangan diskresi (discretionare bevoegdheid) asalkan beleids tersebut tidak bertentangan dengan peraturan perundang-undangan yang ada dan prinsip-prinsip umum penyelenggaraan pemerintahan yang baik tidak boleh sewenang-wenang, menyalahgunakan kekuasaan, dan sebagainya. Kewenangan ketiga adalah membuat peraturan (regeling) dengan syarat bahwa kewenangan membuat peraturan yang disebut Peraturan Menteri adalah kewenangan derevatif/delegatif yang berasal dari presiden, karena menteri adalah pembantunya presiden (H.A.S. Natabaya;2006);177).

Kembali pada persoalan keberadaan dan kekuatan mengikat peraturan perundang-undangan yang diatur dalam Pasal 8 ayat (1) UU 12/2011, termasuk Peraturan Menteri, tidak hanya mengatur keberadaan peraturan perundang-undangan atas dasar delegasi (peraturan yang diperintahkan oleh peraturan perundang-undangan yang lebih tinggi) tetapi juga menegaskan adanya peraturan perundang-undangan "yang dibentuk atas dasar kewenangan".

Istilah "kewenangan" dalam ketentuan tersebut, tentu saja bukan kewenangan membentuk peraturan melainkan kewenangan pada ranah lain. Misalnya, Menteri melaksanakan kewenangan atas urusan pemerintahan tertentu yang merupakan kekuasaan Presiden. Artinya, apabila Menteri membentuk Peraturan Menteri tanpa adanya "perintah dari peraturan 
perundang-undangan yang lebih tinggi", Peraturan Menteri tersebut tetap dikategorikan sebagai peraturan perundang-undangan. Padahal dalam doktrin tidak dikenal jenis peraturan perundang-undangan demikian.

Hal ini perlu dikaji lebih lanjut dari perspektif Ilmu Perundang-undangan terutama dalam kaitannya peraturan perundang-undangan sebagai norma hukum yang bersifat hierarkis dimana norma hukum yang lebih rendah mencari validitasnya pada norma hukum yang lebih tinggi sebagaimana dikemukakan Hans Kelsen atau yang disebut oleh Joseph Raz sebagai chain of validity (Jimly Asshiddiqie \& M. Ali Safa'at; 2006).

Demikian pentingnya, dibutuhkan konsistensi dan kejelasan dalam pemberlakuan norma hukum agar tidak menimbulkan tumpang tindih antar peraturan perundang-undangan dan demi tercapainya kepastian hukum. Dalam Penjelasan Undang Undang Nomor 28 Tahun 2008 Tentang Penyelenggaraan Negara Yang Bersih Dan Bebas Dari Korupsi, Kolusi, Dan Nepotisme, Pasal 3 Angka (1) menyatakan bahwa yang dimaksud dengan "Asas Kepastian Hukum" adalah asas dalam negara hukum yang mengutamakan landasan peraturan perundang-undangan,kepatutan, dan keadilan dalam setiap kebijakan Penyelenggara Negara.

Maria Farida Indrati menyebutkan bahwa setiap norma itu berlaku karena ia mempunyai "daya laku" (validitas) atau karena ia mempunyai keabsahan (validity/geltung) (Maria Farida Indrati, Op. Cit). Secara teoritis, khusus dalam konteks daya laku (geltung), keabsahan suatu norma itu sangat bersinggungan dengan landasan yuridis (juridische gelding) suatu norma hukum. Hal demikian merupakan legitimasi dalam merumuskan suatu norma hukum yang berlaku untuk umum (Jimly Asshiddiqie;2014). Daya laku (geltung) suatu norma ada apabila norma itu dibentuk oleh norma yang lebih tinggi atau oleh lembaga yang berwenang membentukknya.

Kemudian dalam hal norma itu mempunyai daya laku apabila dibentuk oleh norma yang lebih tinggi, atau yang ia sebut landasan yuridis dari segi material, yakni dasar hukum untuk mengatur hal-hal tertentu. Landasan yuridis material menunjuk kepada materi muatan tertentu yang harus dimuat dalam suatu peraturan peundang-undangan tertentu.

Pembentuk

peraturan menghendaki bahwa suatu materi tertentu hendaknya diatur dalam suatu peraturan perundang-undangan tertentu pula. Isi atau substansi suatu peraturan perundang-undangan harus sesuai dengan "wadahnya" atau jenis peraturan perundang-undangan. Selain itu, isi suatu peraturan perundangundangan tidak boleh bertentangan dengan isi peraturan perundangundangan yang derajatnya lebih tinggi (Mukhlis Taib;2017;34).

Masalah keberlakuan hukum ini merupakan suatu hal yang amat penting dalam kontruksi pembentukan norma hukum di Indonesia. Berkaitan dengan Permenkumham 25/2017 jika ditelaah dari sudut keberlakuan suatu norma hukum (geltung) maka akan dapat disimpulkan bahwa pemberlakuannya tidak konsisten dengan aturan main dalam pembentukan suatu peraturan perundang-undangan.

Untuk menguji bagaimana keberlakuan Permenkumham 25/2017 maka dapat mengacu pada ketentuan Pasal 8 ayat (2) UU 12/2011. Kekuatan mengikat Peraturan Menteri sebagai peraturan perundang-undangan salah 
satunya adalah apabila diperintahkan oleh peraturan perundang-undangan yang lebih tinggi. Dalam hal ini tidak ada satupun pasal dalam UUJN yang menyebutkan mengenai Ujian Pengangkatan Notaris.

Pada bagian konsiderans menimbang huruf $b$ Permenkumham 25/2017 disebutkan "bahwa untuk mewujudkan Notaris yang memiliki kompetensi sehingga mampu menjalankan tugas dan kewajiban sesuai dengan ketentuan peraturan perundang-undangan, perlu mengatur pelaksanaan ujian pengangkatan Notaris;". Hal tersebut menunjukkan bahwa Permenkumham 25/2017 merupakan peraturan yang dibentuk berdasarkan kewenangan. Namun permasalahan yang terjadi dengan dibentuknya peraturan berdasarkan kewenangan Menteri tersebut adalah bertentangan dengan Asas-Asas Umum Pemerintahan Yang Baik karena dalam hal ini Permenkumham 25/2017 justru melahirkan suatu norma baru yang bertentangan dengan Pasal 3 UUJN yang mengatur tentang syarat pengangkatan Notaris. Kondisi tersebut dapat dikualifikasikan sebagai bentuk penyalahgunaan wewenang.

\section{Kesimpulan}

Ujian Pengangkatan Notaris diberlakukan agar tercipta adanya standarisasi dan kualitas tinggi dari tiap Notaris yang dapat diangkat. Ujian Pengangkatan Notaris adalah untuk menilai kemampuan calon Notaris, bahwa memang secara nyata mempunyai pengetahuan yang cukup, baik dan layak menjadi seorang Notaris yang akan melayani masyarakat dalam pembuatan alat bukti tertulis berupa akta otentik.

Permenkumham 25/2017 jika ditelaah dari sudut keberlakuan suatu norma hukum (geltung) tidak konsisten dengan aturan main dalam pembentukan suatu peraturan perundang-undangan. Menteri Hukum Dan Hak Asasi Manusia tidak berwenang mengeluarkan persyaratan Ujian Pengangkatan Notaris karena bertentangan dengan Asas-Asas Umum Pemerintahan Yang Baik. Permenkumham 25/2017 melahirkan suatu norma baru yang bertentangan dengan Pasal 3 UUJN yang mengatur tentang syarat pengangkatan Notaris. Kondisi tersebut dapat dikualifikasikan sebagai bentuk penyalahgunaan wewenang.

\section{Saran}

Calon Notaris diharapkan mampu meningkatkan ilmu pengetahuan tentang hukum yang dimilikinya secara mandiri sehingga meskipun tidak melalui adanya Ujian Pengangkatan Notaris tetap dapat dihasilkan Calon Notaris yang memiliki kualitas mumpuni.

Permenkumham 25/2017 tidak memiliki validitas dan bertentangan dengan Asas-Asas Umum Pemerintahan Yang Baik sehingga sudah selayaknya Menteri Hukum Dan Hak Asasi Manusia mencabut Permenkumham 25/2017

\section{Daftar Pustaka Buku-Buku}

A. Hamid S. Attamimmi, Ilmu Perundang - Undangan, Sinar Grafika, Bandung, 1990

A. A. Andi Prajitno, Pengetahuan Praktis Tentang Apa dan Siapa Notaris di Indonesia?Sesuai UUJN Nomor 2 Tahun 2014, Perwira Media Nusantara, Surabaya, 2015

Bagir Manan, Dasar-Dasar Perundangundangan Indonesia, Penerbit INDHILL.CO, Jakarta, 1992 
Freddy Harris dan Leny Helena, Notaris Indonesia, Lintas Cetak Djaja, Jakarta, 2017

G.H.S. Lumban Tobing, Peraturan Jabatan Notaris, Erlangga, Jakarta, 1979

H.A.S. Natabaya, Sistem Peraturan Perundang-Undangan Indonesia, Sekjend Mahkamah Konstitusi, Jakarta, 2006

Habib Adjie, Hukum Notaris Indonesia, Tafsir Tematik Terhadap UU No.30 Tahun 2004 Tentang Jabatan Notaris, Refika Aditama, Bandung, 2008.

Jimly Asshiddiqie, Perihal UndangUndang, Rajawali Pers, Jakarta, 2014,

----- \& M. Ali Safa'at, Teori Hans Kelsen Tentang Hukum, Konpress, Jakarta, 2006

Komar Andasasmita, Notaris I, Sumur Bandung, Bandung, 1981

Maria Farida Indrati, Ilmu Perundangundangan; Jenis Fungsi dan Materi Muatan, Kanisius, Yogyakarta, 2014

Mukhlis Taib, Dinamika PerundangUndangan di Indonesia, Refika Aditama, Bandung, 2017

Pengurus Pusat Ikatan Notaris Indonesia, Jati Diri Notaris Indonesia : Dulu,Sekarang Dan Masa Datang, Gramedia, Jakarta, 2008,

Rusdianto Sesung, dkk., Hukum dan Politik Hukum Jabatan Notaris, R.A.De Rozarie, Surabaya, 2017

Suhardjono, Sekilas Tinjauan Akta Menurut Hukum, Varia Peradilan, Nomor 123, 1995,

Tan Thong Kie, Studi Notariat, SerbaSerbi Praktek Notaris, Buku I, Ichtiar Baru,Jakarta, 2000

\section{Makalah}

Hatta Isnaini Wahyu Utomo, "Pelaksanaan Tugas Jabatan Notaris : Bahan Diskusi Dalam Persiapan Menghadapi Ujian Kode Etik Notaris", Makalah, disampaikan pada acara Belajar Bareng Alumni, Universitas Narotama Surabaya, Februari 2018 